\title{
Management of capitellar fractures with open reduction and internal fixation using Herbert screws
}

\author{
Asif Sultan, M.S., Omar Khursheed, M.S., Mohammad Rafiq Bhat, M.S., \\ Hilal Ahmad Kotwal, M.S., Qazi Waris Manzoor, M.S. \\ Department of Orthopedic Surgery, Government Hospital for Bone \& Joint Surgery, Barzulla, Srinagar-India
}

\begin{abstract}
BACKGROUND: Capitellar fractures are rare elbow injuries and can cause severe limitation of function if not properly managed. Numerous treatments have evolved, from closed reduction and cast immobilization to open reduction and internal fixation (ORIF), so as to achieve a stable joint that allows early mobilization. We determined the functional outcomes of treating these fractures with ORIF using Herbert screws via an extensile lateral approach.
\end{abstract}

METHODS: Fifteen patients with capitellar fractures were included in this retrospective study. A well taken lateral radiograph was important and stressed upon in all patients. All fractures were open reduced and internally fixed using Herbert screws via an extensile lateral approach over a period of 5 years. Clinical, radiographic, and Mayo Elbow Performance Index were evaluated at a mean followup of 3.6 years (range, I.5-6 years).

RESULTS: Nine type I and six type IV capitellar fractures were identified using Bryan and Morrey classification system. The average time to bone union was 12 weeks (range 8-16 weeks) with no case of nonunion. The mean range of flexion was $130^{\circ}$ (range $\left.125^{\circ}-135^{\circ}\right)$. The average extensor lag was $10^{\circ}\left(\right.$ range $\left.0^{\circ}-30^{\circ}\right)$, with a functional range of motion of elbow achieved in all patients. On the final follow-up, one case of osteoarthritis was seen, but no evidence of avascular necrosis or heterotrophic ossification was seen. Two patients needed screw removal. The outcome was excellent in 10 patients and good in five patients.

CONCLUSION: Herbert screw fixation provides stable fixation in capitellar fractures and good to excellent outcomes with excellent elbow motion, can be achieved following internal fixation of these complex fractures using the extended lateral exposure.

Keywords: Capitellar fracture; extended lateral exposure; Herbert screw; open reduction and internal fixation.

\section{INTRODUCTION}

Intraarticular coronal shear fractures of the capitellum are rare injuries and account for approximately $1 \%$ of all elbow fractures and $6 \%$ of all distal humeral fractures. ${ }^{[1,2]}$ Capitellar fracture was first described by Cooper ${ }^{[3]}$ as an isolated injury in 1841, followed by $\mathrm{Hahn}^{[4]}$ in 1853, who also reported an isolated capitellar fracture in a 63-year-old woman who had poor results due to loss of elbow flexion. The classification of capitellar fractures into two types evolved after further

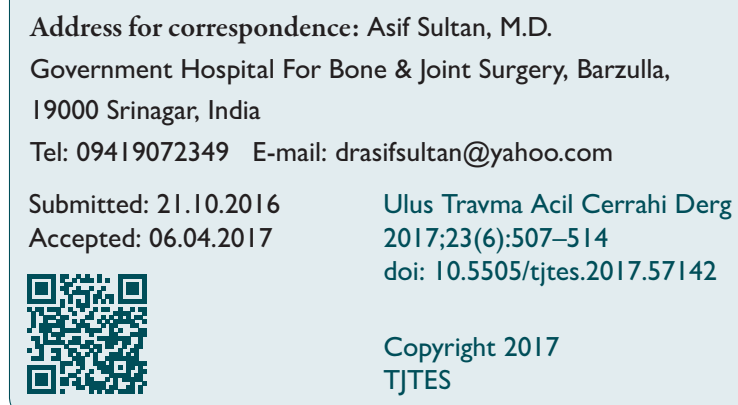

reports of this injury by Kocher ${ }^{[5]}$ in 1896 , Steinthal ${ }^{[6]}$ in 1898 , and Lorenz ${ }^{[7]}$ in 1905: type I or "Hahn-Steinthal" fracture and type II or "Kocher-Lorenz" fracture. Capitellar injuries are typically due to its axial loading by forces transmitted through the radial head. ${ }^{[8,9]}$ The fracture is caused by a fall onto the outstretched hand with the elbow in extension or in slight flexion. The impact on the hand creates a force that passes through the forearm to the head of the radius, which acts like a piston and shears off the capitellum. ${ }^{[10]}$ Capitellar fractures can be sustained either by a direct injury with the elbow in flexion or indirectly through an extended radius, as in falling on an outstretched hand. ${ }^{\left[{ }^{I I}\right]}$ Nevertheless, both these mechanisms can produce a coronal shear fracture. Radial head fractures are associated with indirect trauma and are likely to be present in approximately $24 \%$ of patients. ${ }^{[I]}$

Presently, the Bryan and Morrey ${ }^{[12]}$ classification for capitellar fractures into three types with McKee et al. ${ }^{[9]}$ adding a fourth type is in common use. In the AO classification system, ${ }^{[13]}$ capitellar fractures would be identified as I 3 B3 (distal end of the humerus, partial articular, and frontal), with B3.I indicat- 
ing isolated capitellar fractures; B3.2, trochlear fractures; and B3.3, capitellar and trochlear fractures.

Many treatments and management methods have been advocated and include closed reduction and immobilization, ${ }^{[14]}$ fracture fragment excision, ${ }^{[15]}$ open reduction with or without internal fixation ${ }^{[16-22]}$ using Kirschner wires (K-wires), cannulated screws or Herbert screws, ${ }^{[23-26]}$ and prosthetic replacement. ${ }^{[27]}$ Herbert screw provides some definite advantages over other methods of internal fixation. It achieves better fracture site compression, provides stable fixation without damaging the articular cartilage, allowing early joint motion and less or no need for second stage hardware removal. ${ }^{[23,28]}$

We present a retrospective study of 15 cases of capitellar fractures treated using Herbert screw fixation over a period of 4 years with a mean follow-up of 3.6 years. The purpose of this present study was to perform an objective and subjective evaluation with functional outcome of patients with capitellar fractures that were treated with internal fixation by inserting Herbert screws in an anterior-to-posterior direction after open reduction via an extensile lateral approach.

\section{MATERIALS AND METHODS}

Fifteen patients with capitellar fractures were treated from January 2010 to December 2014 and were followed up till July 2016. Patients included II female and 4 male patients aged 20-48 years (mean, 35 years), with fracture of the dominant right-hand elbow in three and nondominant left-hand elbow in 12 patients. Inclusion criteria were closed fractures in skeletally mature patients and exclusion criteria were joint laxity and prior degenerative or inflammatory arthritis. All fractures were closed and had occurred following a fall onto the flexed elbow in six or with outstretched hand in nine patients. Distal neurovascular examination of the limb was normal. All patients underwent plain radiographs (anteroposterior and lateral), and $\mathrm{CT}$ scan with 3D reconstructions was performed only in cases with associated radial head and epi- condyle fractures. Fractures were classified according to the Bryan and Morrey classification and were of type I in nine and type IV in six patients. According to the AO classification, nine were of I 3 B3.I and six of I3 B3.3 type. Two patients had associated radial head fractures and one had lateral epicondyle fracture. All patients were operated within 7 days after injury.

Patients were operated under general or regional anesthesia, with the patient in supine position. A pneumatic tourniquet was used in all cases. Varus and valgus stress tests were performed to rule out any ligamentous instability. Open reduction of fractures was performed via an extensile lateral approach. ${ }^{[9,25,29,30]}$ A skin incision was made laterally at the elbow, centering over the lateral epicondyle and extending proximally $4-6 \mathrm{~cm}$ over the distal end of the humerus to approximately $2 \mathrm{~cm}$ distal to the radial head. Dissection was performed through the subcutaneous tissue layers, and the lateral column was identified along with the common extensor origin. The forearm is pronated to avoid any iatrogenic injury to the radial nerve, moving it away from the operating area. The common origin of the radial wrist extensors along with the anterior capsule of the elbow joint was sharply elevated as a single full-thickness flap from the lateral supracondylar ridge anterosuperiorly and distally connected to the "Kocher interval" to reach the fracture site, which was cleared of hematoma and soft-tissue debris so as to allow the proper visualization and orientation of the fracture using normal saline irrigation (Fig. Ia).

Due care was taken to preserve the lateral ulnar collateral ligament origin at the lateral epicondyle along with vascular supply to the capitellum. Anatomic reduction was directly visualized as the fractured capitellum was reduced along the proximal metaphyseal margin and trochlea medially . Capitellar fractures were fixed using two headless cannulated Herbert screws, which were inserted over the guidewires in an anterior-to-posterior direction (Fig. Ib). Screws were sunk
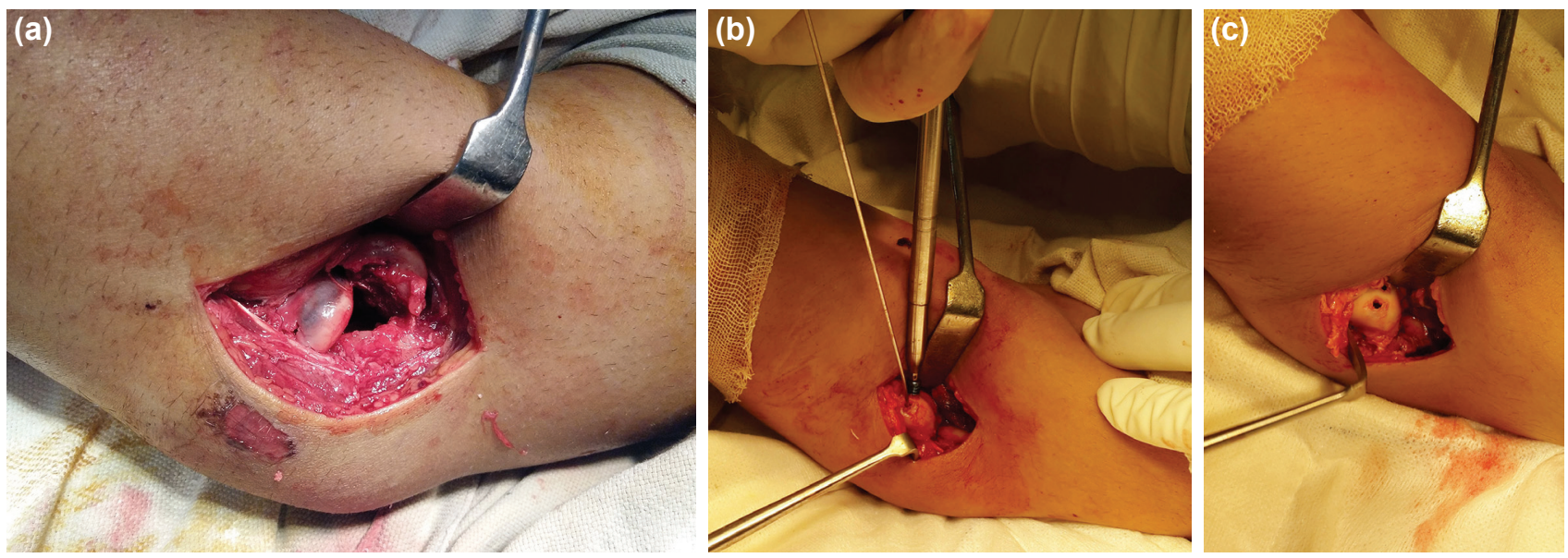

Figure 1. (a) Exposed capitellar fracture lying anterior to the radial head. (b) Headless cannulated Herbert screws being inserted over the guidewires in an anterior-to-posterior direction. (c) Herbert screws are sunk beneath the articular surface. 
Table I. Demographic data of patients, fracture type, and associated injuries

\begin{tabular}{|c|c|c|c|c|c|c|c|}
\hline Patient & $\begin{array}{c}\begin{array}{c}\text { Age } \\
\text { (years) }\end{array}\end{array}$ & Sex & $\begin{array}{c}\text { Side } \\
\text { involved }\end{array}$ & $\begin{array}{c}\text { Dominant(D)/ } \\
\text { nondominant arm (ND) }\end{array}$ & $\begin{array}{l}\text { Etiology: } \\
\text { fall on }\end{array}$ & $\begin{array}{c}\text { Fracture } \\
\text { type }\end{array}$ & $\begin{array}{l}\text { Associated } \\
\text { injury/fracture }\end{array}$ \\
\hline I & 33 & Female & Left & ND & Flexed elbow & IV & \\
\hline 2 & 34 & Female & Left & ND & Outstretched hand & 1 & \\
\hline 3 & 29 & Female & Left & ND & Flexed elbow & IV & \\
\hline 4 & 48 & Male & Left & ND & Outstretched hand & 1 & \\
\hline 5 & 32 & Female & Left & ND & Outstretched hand & I & \\
\hline 6 & 20 & Male & Right & D & Flexed elbow & IV & Lateral epicondyle \\
\hline 7 & 31 & Female & Left & ND & Outstretched hand & I & \\
\hline 8 & 39 & Female & Left & ND & Outstretched hand & IV & Radial head \\
\hline 9 & 45 & Male & Left & ND & Flexed elbow & 1 & \\
\hline 10 & 43 & Female & Right & D & Flexed elbow & I & \\
\hline II & 38 & Male & Right & $\mathrm{D}$ & Outstretched hand & 1 & Radial head \\
\hline 12 & 31 & Female & Left & ND & Outstretched hand & I & \\
\hline 13 & 38 & Female & Left & ND & Flexed elbow & IV & \\
\hline 14 & 36 & Female & Left & ND & Outstretched hand & I & \\
\hline 15 & 28 & Female & Left & ND & Outstretched hand & IV & \\
\hline
\end{tabular}

into the articular surface to avoid any damage to the radial head or impingement (Fig. Ic). The common wrist extensor origin was repaired back to soft tissues and periosteum over the lateral supracondylar ridge. The wound was closed in two layers. Radial head fractures in two patients were addressed through the same exposure and fixed using headless screws. The lateral epicondyle fracture in one patient was too small for screw fixation and was fixed using two K-wires, which were removed after 6 weeks.

Compressive sterile dressing was applied, and the arm was placed in a long arm posterior plaster slab and with the elbow kept in flexion of around $90^{\circ}$. The plaster slab was removed after I week, and the sutures were removed and active range of motion exercises of the elbow and forearm were started. Strengthening exercises were delayed till clinical and radiographic evidence of bone union was seen.

All patients were evaluated using the Mayo Elbow Performance Index (MEPI) Score for function, stability, pain, and range of motion (ROM) at the elbow. Radiographs were assessed for the status of bone union, signs of avascular necrosis (AVN), and osteoarthritis. Further assessment was also performed for wound complications, elbow function, and any other complications. The length of follow-up ranged from I.5 to 6 years (mean of 3.6 years).

\section{RESULTS}

Demographic data are displayed in Table I. Nine type I and six type IV fractures were identified in this series. All patients were right-handed. The dominant hand was injured in three cases only. The mechanism of injury was a low-energy fall in all cases. All fractures were closed. There were no associated neurovascular injuries. There were two ipsilateral radial head fractures and one lateral epicondyle fracture. No other concomitant upper limb musculoskeletal injuries were observed. Intraoperatively, trochlear involvement was identified in association with all type IV fractures. The lateral collateral ligament was intact in all fractured elbows, except in one where the lateral collateral ligament was found to be avulsed along with an attached lateral epicondyle fracture fragment.

All fractures united well and the mean time to union was 12 weeks, ranging from 8 to 16 weeks (Fig. 2a, b). No patient had any residual elbow instability or weakness. Extensor power and grip strength were similar to that of the other side. Forearm rotations were not restricted in any of our patients including those with radial head fractures. The average range
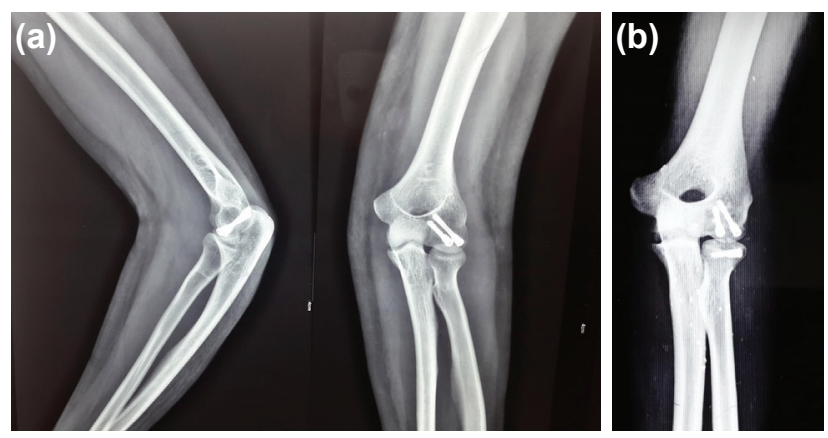

Figure 2. (a) Final lateral and anteroposterior radiograph following fixation of a type IV capitellar fracture shows union without any sign of avascular necrosis or arthritis. (b) Anteroposterior radiograph showing union of the capitellar and radial head fractures. 
Table 2. Data of patients showing functional and clinical outcomes with MEPI score and complications

\begin{tabular}{|c|c|c|c|c|c|c|c|}
\hline Patient & $\begin{array}{l}\text { Follow-up } \\
\text { (years) }\end{array}$ & Reoperation & Complications & $\begin{array}{l}\text { MEPI } \\
\text { score }\end{array}$ & $\begin{array}{c}\text { Range of motion in elbow } \\
\text { in degrees (normal flexion - } \\
\text { extension } 0^{\circ}-135^{\circ} \text { ) }\end{array}$ & $\begin{array}{l}\text { Days from } \\
\text { injury to } \\
\text { surgery }\end{array}$ & $\begin{array}{c}\text { Extension } \\
\text { lag in } \\
\text { degrees }\end{array}$ \\
\hline I & 6 & & & 85 & $15-135$ & 7 & 15 \\
\hline 2 & 5.6 & & & 90 & $10-135$ & 3 & 10 \\
\hline 3 & 5.4 & Removal of screws & Extension loss of $25^{\circ}$ & 85 & $25-135$ & 3 & 25 \\
\hline 4 & 4.6 & & & 90 & $10-135$ & 3 & 10 \\
\hline 5 & 4.3 & & & 100 & $0-135$ & 3 & 0 \\
\hline 6 & 4 & $\begin{array}{l}\text { Removal of screws } \\
\text { and K-wires }\end{array}$ & $\begin{array}{c}\text { Extension loss of } 30^{\circ} . \\
\text { Arthritis }\end{array}$ & 75 & $30-125$ & 7 & 30 \\
\hline 7 & 3.8 & & & 100 & $0-135$ & 3 & 0 \\
\hline 8 & 3.6 & & & 85 & $15-130$ & 3 & 15 \\
\hline 9 & 3.5 & & & 100 & $0-135$ & 3 & 0 \\
\hline 10 & 3.2 & & & 90 & $10-130$ & 3 & 10 \\
\hline II & 2.5 & & & 85 & $15-125$ & 3 & 15 \\
\hline 12 & 2.2 & & & 100 & $0-135$ & 3 & 0 \\
\hline 13 & 2 & & & 90 & $10-130$ & 3 & 10 \\
\hline 14 & 1.8 & & & 100 & $0-135$ & 3 & 0 \\
\hline 15 & 1.5 & & & 95 & $10-135$ & 3 & 10 \\
\hline
\end{tabular}

MEPI: Mayo Elbow Performance Index.

of flexion was $130^{\circ}$ (range, $\left.125^{\circ}-135^{\circ}\right)$. The mean extensor lag was $10^{\circ}$ (range, $0^{\circ}-30^{\circ}$ ), with the ROM of the elbow remaining functional in all patients (Table 2). One patient had restriction of elbow extension due to the screw being too long and protruding into the olecranon fossa, thus impinging on the olecranon and not allowing full extension of the elbow. The screws in this patient were removed after 4 months of the primary procedure with some gain in extension. The mean extension lag was $17.5^{\circ} \pm 8.12$ in six patients with type IV fracture compared with $5^{\circ} \pm 5.83$ in nine patients with type I fracture ( $t=3.49, p=0.0040$ which is significant $)$.

Post-traumatic arthritis was seen in one elbow; despite radiographic evidence of arthritis, the clinical and functional result was good. At the final follow-up, no evidence of AVN or heterotrophic ossification was seen in radiographs.

All patients returned to their preinjury level of work status. Outcomes were excellent in 10 patients and good in 5 with a mean score of $91.33 \pm 7.4$ (range, 75-100) at the latest follow-up as per the MEPI, which takes pain, motion, stability, and function into consideration. Among patients with type I fracture, the mean MEPI score was $95 \pm 7.69$ compared with $85.83 \pm 7.4 \mathrm{I}$ among patients with type IV fracture $(\mathrm{t}=2.29$, $p=0.039$ I, which is statistically significant).

\section{DISCUSSION}

Despite its rarity, the prevalence of capitellar fractures is four times higher in women than in men, ${ }^{[10,31]}$ and it has been sug- gested that this is due to the greater carrying angle in females along with weaker bones (osteoporosis). ${ }^{[1]}$ These injuries mostly occur in young persons, and the female preponderance seen in the present series coincides well with the reported literature. ${ }^{[3 !]}$

Patients with capitellar fractures mostly present with painful swelling of the elbow immediately after an injury. These fractures are often missed on the first examination, ${ }^{[28]}$ as these cannot be clearly seen on anteroposterior radiographs because the fracture lines are not well recognizable against the profile of the distal humerus because of the overlap. They are typically picked and best seen on true lateral views (Fig. $3 a, b) .{ }^{[28]}$ A high index of suspicion and good lateral view radiograph is thus warranted to avoid missing this injury. Additionally, in type IV injuries on a lateral view radiograph, a pathognomonic "double arc sign" formed by the overlap of subchondral bone of the capitellum and the trochlear ridge is often seen (Fig. 4a, b). ${ }^{[9]}$

CT scan with 3D reconstructions is usually advised to delineate the medial extent, articular impaction with metaphyseal, or condylar comminution of the fracture. ${ }^{[32]} \mathrm{CT}$ scans may be used to properly delineate and classify the fracture preoperatively. We did not routinely perform CT scan in our patients, except in cases with associated injuries around the elbow.

The most frequent type of capitellar fracture is type I (HahnSteinthal), which accounts for $47 \%$ of all fractures, and the 

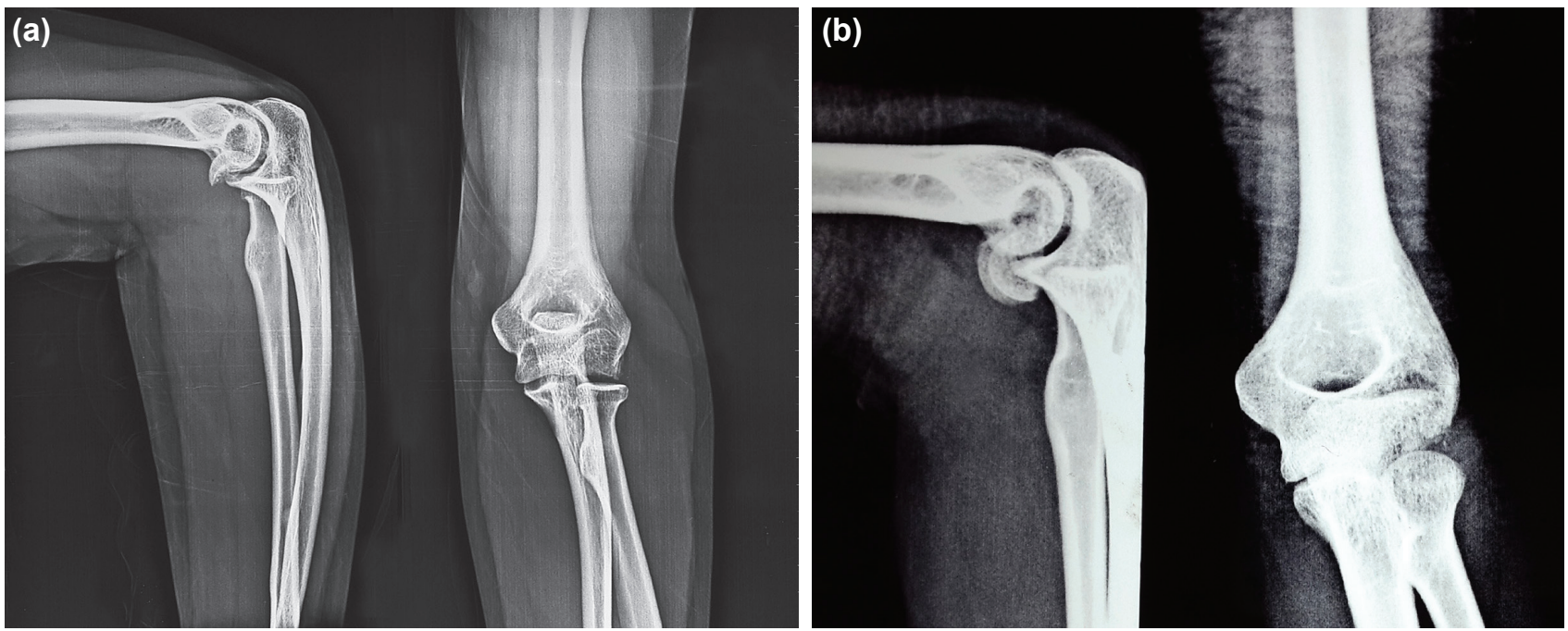

Figure 3. (a, b) Anteroposterior and lateral radiographs demonstrating difficulty in identifying capitellar fracture in anteroposterior views, but picked on lateral views.
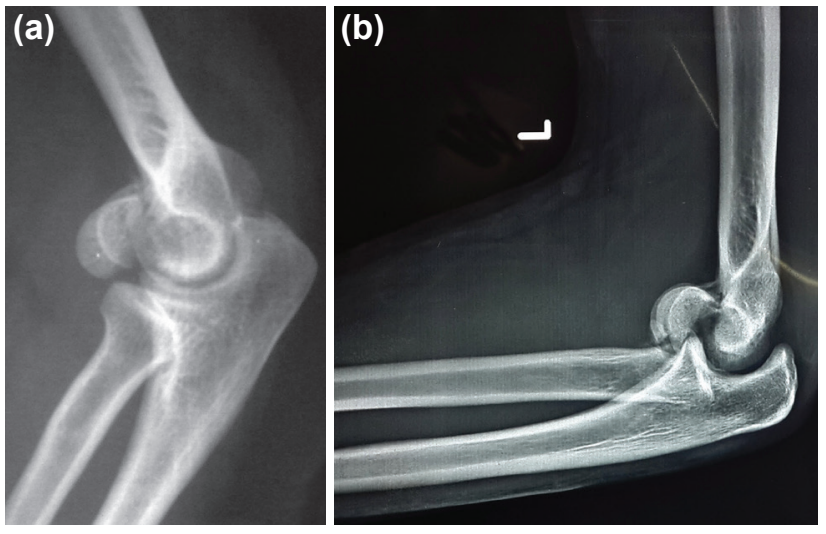

Figure 4. (a, b) Lateral views showing "double arc sign" in type IV capitellar fractures.

majority of them occur due to fall from standing height. ${ }^{[14]}$ In our study, nine patients were categorized into type I. Type II (Kocher-Lorenz) and type III (comminuted) fractures are found in significantly lower numbers. No type II or type III cases were present in this study. Type IV (McKee) accounts for approximately $36 \%$ of capitellar fractures in women and $54 \%$ in men. ${ }^{[14]}$ In our study of 15 cases, there were six type IV fractures. Capitellar fractures with radial head fracture occurs in $24 \%$ of cases. ${ }^{\left[{ }^{[14]}\right.}$ This series had two cases with radial head fractures and one with associated fracture of lateral epicondyle.

Although there are many different treatment modalities described for capitellar fractures, including closed reduction and immobilization, ${ }^{[14]}$ excision of fracture fragments, ${ }^{[15]}$ prosthetic replacement, ${ }^{[27]}$ ORIF is presently considered as the best treatment. ${ }^{[9,26,32]}$ Fixation has been achieved using K-wires, cancellous screws ${ }^{[2,30]}$ inserted from the posterior to anterior direction, and Herbert screws. ${ }^{[23-26]}$ We used Herbert screws in our series, as fixation of the capitellar fracture us- ing these screws has been found to be better than using Kwires or cancellous lag screws, ${ }^{[33]}$ directed from the anterior to the posterior direction, as this eliminates the need for further soft-tissue dissection from the posterolateral aspect of condyle, besides achieving good fixation. Herbert screws are terminally threaded, providing fracture site compression through their variable thread pitch designs. The head is buried beneath the articular surface so that it does not hinder joint mobility. This also reduces the need of repeat surgery for screw removal. ${ }^{[28]}$ Two screws were always used to ensure a good rotational control.

We used an extensile lateral approach, ${ }^{[9,25,29,30]}$ a common surgical approach in all patients as it provides adequate exposure to address any extension of the trochlea medially, any impaction, and/or comminution present type IV fractures, thus eliminating the need for the second approach. The skin incision is small, not larger than $6-8 \mathrm{~cm}$. Further, neurovascular structures are not at risk, and radial head and lateral epicondylar fractures can be simultaneously addressed.

Complication rates in our series were few and less than that reported in the literature. ${ }^{[9,34]}$ Two of our patients require reoperations for screw removal, with no influence on the final functional result. One screw was limiting extension, as it was protruding into the olecranon fossa, which improved after its removal (Fig. 5). To prevent screw impingement like this, we recommend routine use of fluoroscopy during surgery so that proper position and screw length will be chosen. We had one post-traumatic osteoarthritis, and it has also been documented in other series (Fig. 6a, b). ${ }^{[9,30,32]}$ The fracture had severe medial comminution and impaction along with lateral epicondylar comminuted fracture. Screws in this patient were also removed. Anatomical reduction of the fracture with careful handling of articular cartilage is critical in preventing arthritis. 


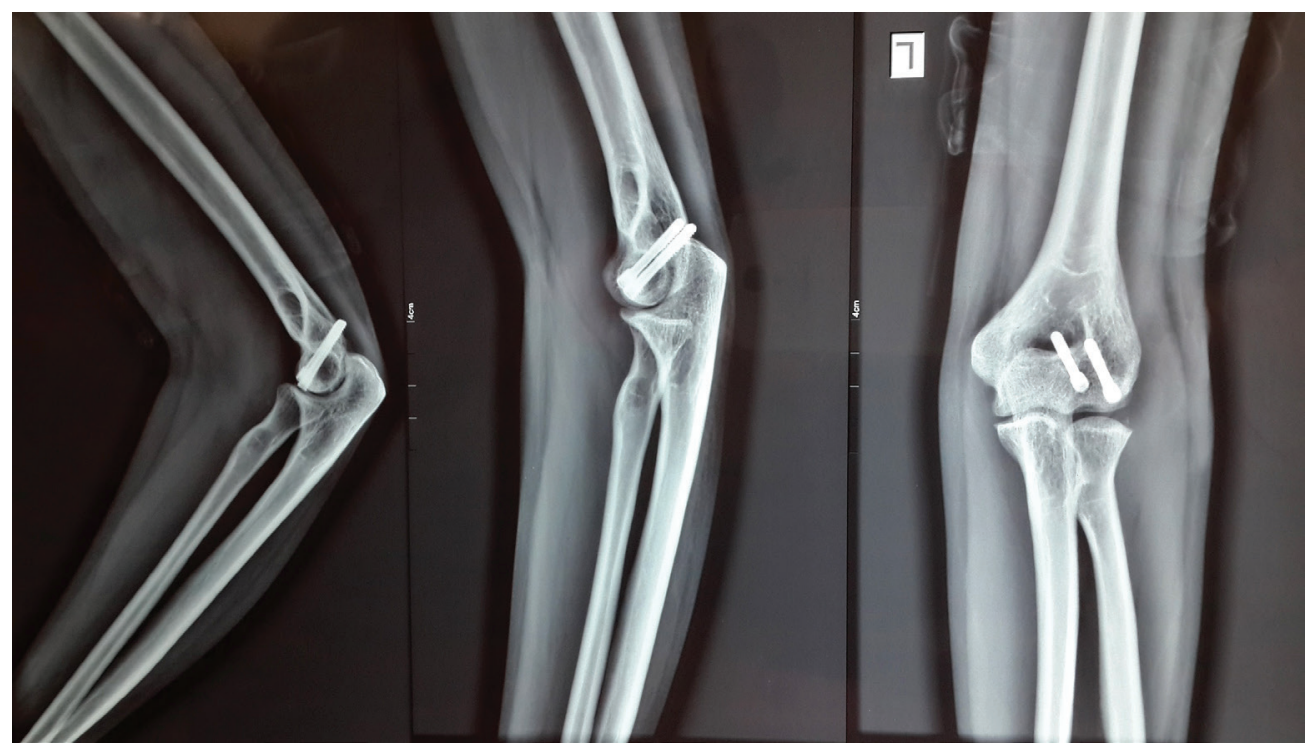

Figure 5. Radiograph showing long screw impinging into the olecranon fossa.
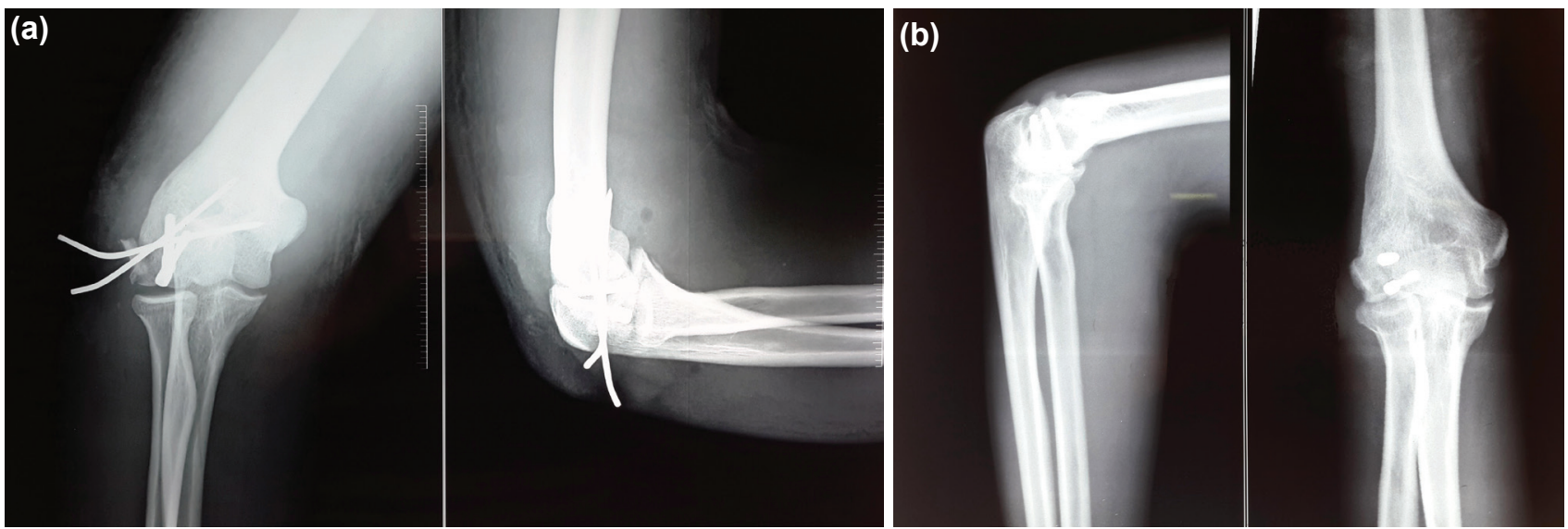

Figure 6. (a) Postoperative anteroposterior and lateral radiographs of the capitellum with lateral epicondylar fracture following surgery showing fixation with K-wires for epicondyle along with Herbert screws for the capitellum and (b) at 4 years showing arthritic changes.

Limitation of the elbow motion (flexion and extension) and residual pain are the most common complications associated with capitellar fractures, but forearm rotations (pronation and supination) are rarely affected. ${ }^{[24,32]}$ Flexion was not limited much in our series compared with the normal arm $\left(0^{\circ}-135^{\circ}\right)$, one patient with arthritis has loss of terminal $10^{\circ}$ of flexion. Ten of our patients had an extension lag of $10^{\circ}-25^{\circ}$ but two of our patients had more extension loss due to implant impingement and arthritis. Screw removal was performed in both cases with improvement seen in only the impingement case. The extension lag was statistically significant $(p=0.0040)$ between type I and type IV fractures; mean extension lag was $17.5^{\circ} \pm 8.12$ in six patients with type IV fracture compared with $5^{\circ} \pm 5.83$ in nine patients with type I fracture. Thus, reduction in the ROM of the elbow is seen more commonly in type IV injuries.

Articular damage and deformity, intraarticular or extraarticular adhesions, and prolonged immobilization being major factors causing loss of elbow motion. ${ }^{[35]}$ Accurate anatomical reduction of fracture, stable fixation and early mobilization are keys to achieve painless full motion with desired functional results. ${ }^{[32]}$

MEPI according to fracture subgroup is presented in Table 3. Among patients with type I fractures, eight had excellent and one had good results, and in patients with type IV fracture, two had excellent and four had good results. Although type I fracture has better functional outcome than type IV fracture,

Table 3. Mayo elbow performance index (MEPI) according to the fracture subgroup

\begin{tabular}{lcc}
\hline MEPI & Type I & Type IV \\
\hline Excellent & 8 & 2 \\
Good & 1 & 4 \\
\hline
\end{tabular}


the difference is not statistically significant $(p=0.0889$; Fisher's exact test).

Although the overall incidence of AVN has been reported in the literature to be $0 \%-30 \%$ in capitellar fractures, ${ }^{[9,28,36]}$ none of our cases showed any signs of AVN at the latest follow-up radiographs, even when most of the times, major fracture fragments were devoid of soft-tissue attachments. With the incidence of AVN being very low, it is always advisable to fix a large free capitellar fragment. ${ }^{[35]}$

Heterotopic ossification has not been usually seen with these fractures. ${ }^{[32]}$ In our series, no case of heterotrophic ossification was seen and no prophylaxis to prevent the same was given. Early surgical management and good rehabilitation may be a preventing factor, as earlier management of these fractures reduces the risk of developing heterotopic ossification. ${ }^{[37]}$

Our case series shows that ORIF for capitellar fractures using Herbert screws inserted from the anterior to the posterior direction through extensile lateral approach is safe and easy, achieving rigid fixation that allows early mobilization with minimal minor complications, thus achieving excellent outcomes with good elbow motion and function.

\section{Conflict of interest: None declared.}

\section{REFERENCES}

1. Harrington JP,Mckee MD. Coronal Shear fractures of the capitellum and trochlea. Tech Shoulder Elbow Surg 2000;1:240-6. [CrossRef]

2. Jupiter JB, Morrey BF. Fractures of the distal humerus in the adult. In: Morrey BF editor. The elbow and its disorders. 2nd ed. WB Saunders, Philadelphia: 1993; p. 328-66.

3. Cooper SAP. Fractures of the external condyle of the humerus. In: Lee, Cooper SAP, editors. A treatise on dislocations and fractures of the joints. 1st ed. London: Joseph Butler; 1841. p. 508.

4. Hahn NF. Fall von einer besonderen Varietät der Frakturen des Ellenbogens. Zeitschrift fur Wundärzte und Geburtshelfer 1853;6:1859.

5. Kocher T. Beiträge zur Kenntniss einiger praktisch wichtiger Frakturformen. Basel: Carl Sallmann; 1896:585-91.

6. Steinthal D. Die isolierte Fraktur der Eminentia Capitata im Ellenbogengelenk. Zentralbl Chirurgie 1898;15:1.

7. Lorenz H. Zur Kenntniss der Fractura Capitelulm Humeri (Eminentia Capitata). Deutsche Zeitschr f Chir.1905;78:531-45. [CrossRef]

8. Silveri CP, Corso SJ, Roofeh J. Herbert screw fixation of a capitellum fracture. A case report and review. Clin Orthop Relat Res 1994:123-6.

9. McKee MD, Jupiter JB, Bamberger HB. Coronal shear fractures of the distal end of the humerus. J Bone Joint Surg Am 1996;78:49-54.

10. Lansinger O, Måre K. Fracture of the capitulum humeri. Acta Orthop Scand 1981;52:39-44. [CrossRef]

11. Watts AC, Morris A, Robinson CM. Fractures of the distal humeral articular surface. J Bone Joint Surg Br 2007;89:510-5. [CrossRef]

12. Bryan RS, Morrey BF. Fractures of the distal humerus. In: Morrey BF, editor. The elbow and its disorders. 1st ed. Philadelphia: WB Saunders; 1985. p. 302-39.
13. Mueller ME, Nazarian S, Koch P, Schatzker J. The comprehensive classification of fractures of long bones. New York: Springer; 1990. [CrossRef]

14. Ochner RS, Bloom H, Palumbo RC, Coyle MP. Closed reduction of coronal fractures of the capitellum. J Trauma 1996;40:199-203. [CrossRef]

15. Fowles JV, Kassab MT. Fracture of the capitulum humeri. Treatment by excision. J Bone Joint Surg Am 1974;56:794-8. [CrossRef]

16. Holdsworth BJ, Mossad MM. Fractures of the adult distal humerus. Elbow function after internal fixation. J Bone Joint Surg Br 1990;72:362-5.

17. Jupiter JB, Neff U, Regazzoni P, Allgower M. Unicondylar fractures of the distal humerus: an operative approach. J Orthop Trauma 1988;2:102-9.

18. Liberman N, Katz T, Howard CB, Nyska M. Fixation of capitellar fractures with the Herbert screw. Arch Orthop Trauma Surg 1991;110:1557. [CrossRef]

19. McKee MD, Jupiter JB. A contemporary approach to the management of complex fractures of the distal humerus and their sequelae. Hand Clin 1994;10:479-94.

20. Mosheiff R, Liebergall M, Elyashuv O, Mattan Y, Segal D. Surgical treatment of fractures of the capitellum in adults: a modified technique. J Orthop Trauma 1991;5:297-300. [CrossRef]

21. Poynton AR, Kelly IP, O'Rourke SK. Fractures of the capitellum-a comparison of two fixation methods. Injury 1998;29:341-3. [CrossRef]

22. Farooq M, Mir BA, Farooq M. Coronal shear fractures of the capitellum. Indian Journal of Orthopedics 2004;38:4:259-60.

23. Singh AP, Singh AP, Vaishya R, Jain A, Gulati D. Fractures of capitellum: a review of 14 cases treated by open reduction and internal fixation with Herbert screws. Int Orthop 2010;34:897-901. [CrossRef]

24. Mighell MA, Harkins D, Klein D, Schneider S, Frankle M. Technique for internal fixation of capitellum and lateral trochlea fractures. J Orthop Trauma 2006;20:699-704. [CrossRef]

25. Ruchelsman DE, Tejwani NC, Kwon YW, Egol KA. Open reduction and internal fixation of capitellar fractures with headless screws. J Bone Joint Surg Am 2008;90:1321-9. [CrossRef]

26. Vaishya R, Vijay V, Jha GK, Agarwal AK. Open reduction and internal fixation of capitellar fracture through anterolateral approach with headless double-threaded compression screws: a series of 16 patients. J Shoulder Elbow Surg 2016;25:1182-8. [CrossRef]

27. Jakobsson A. Fracture of the capitellum of the humerus in adults; treatment with intra-articular chrom-cobolt-molybdenum prosthesis. Acta Orthop Scand 1957;26:184-90.

28. Mahirogullari M, Kiral A, Solakoglu C, Pehlivan O, Akmaz I, Rodop O. Treatment of fractures of the humeral capitellum using herbert screws. J Hand Surg Br 2006;31:320-5. [CrossRef]

29. Ruchelsman DE, Tejwani NC, Kwon YW, Egol KA . Open reduction and internal fixation of capitellar fractures with headless screws.s urgical technique. J Bone Joint Surg [Am] 2009;91 Suppl 2:38-49. [CrossRef]

30. Dubberley JH, Faber KJ, Macdermid JC, Patterson SD, King GJ. Outcome after open reduction and internal fixation of capitellar and trochlear fractures. J Bone Joint Surg Am 2006;88:46-54. [CrossRef]

31. Grantham SA, Norris TR, Bush DC. Isolated fracture of the humeral capitellum. Clin Orthop Relat Res 1981:262-9. [CrossRef]

32. Ruchelsman DE, Tejwani NC, Kwon YW, Egol KA. Coronal plane partial articular fractures of the distal humerus: current concepts in management. J Am Acad Orthop Surg 2008;16:716-28. [CrossRef]

33. Elkowitz SJ, Polatsch DB, Egol KA, Kummer FJ, Koval KJ. Capitellum fractures: a biomechanical evaluation of three fixation methods. J Orthop Trauma 2002;16:503-6. [CrossRef]

34. Ring D, Jupiter JB, Gulotta L. Articular fractures of the distal part of the humerus. J Bone Joint Surg Am 2003;85-A:232-8. [CrossRef] 
35. Mehdian H, McKee MD. Fractures of capitellum and trochlea. Orthop Clin North Am 2000;31:115-27. [CrossRef]

36. Ong KL, Mahadev A. Cannulated cancellous screw fixation for capitellum fractures in adolescents. J Orthop Surg (Hong Kong) 2011;19:346-9.

37. Ilahi OA, Strausser DW, Gabel GT. Post-traumatic heterotopic ossification about the elbow. Orthopedics 1998;21:265-8.

\title{
OLGU SERİİ - ÖZET
}

\section{Aç1k redüksiyon ve Herbert vidalarıyla internal fiksasyon yöntemiyle kapitellar kırıkların tedavisi}

\section{Dr. Asif Sultan, Dr. Omar Khursheed, Dr. Mohammad Rafiq Bhat,} Dr. Hilal Ahmad Kotwal, Dr. Qazi Waris Manzoor,

\author{
Kemik ve Eklem Hastalıkları Devlet Hastanesi, Ortopedi ve Travmatoloji Kliniği, Barzulla, Srinagar-Hindistan
}

AMAÇ: Kapitellar kırıklar seyrek görülen dirsek yaralanmaları olup uygun biçimde tedavi edilmediğinde ağır fonksiyonel kısıtlamaya neden olabilirler. Erkenden mobilizasyona olanak sağlayan stabil bir eklem durumunu gerçekleştirmek için kapalı redüksiyon ve alçıla tespitten açık redüksiyon ve internal fiksasyona (ARIF) kadar sayısız tedavi geliştirilmiştir. Geniş bir lateral yaklaşım yoluyla Herbert vidaları ve ARIF yöntemi kullanarak bu kırıkları tedavi etmenin fonksiyonel sonuçlarını belirledik.

GEREÇ VE YÖNTEM: Bu geriye dönük çalışmaya kapitellar kırıkları olan 15 hasta dahil edildi. İyi çekilmiş bir radyografi önemli olduğundan her hastada bu husus vurgulandı. Beş yılıı çalışma dönemi boyunca tüm kırıklar geniş bir lateral ekspozürle açık redüksiyon ve Herbert vidaları kullanılarak internal fiksasyonla tedavi edildi. Ortalama 3.6 yıllık (dağılım, I.5-6 yıl) takipte klinik, radyografik bulgular ve Mayo Dirsek Performans İndeksine göre değerlendirmeler yapıldı.

BULGULAR: Bryan ve Morrey sınıflandırma sistemi kullanılarak 9, tip I ve 6 tip IV kapitellar kırık tespit edildi. Kemiğin kaynamasına kadar ortalama 12 hafta (dağılım, 8-16 hafta) geçmiş, tüm kırıklar kaynadı. Ortalama fleksiyon genişliği $130^{\circ}$ (dağılım, $125^{\circ}$ - I35 $)$ idi. Hastaların tümünde fonksiyonel hareket aralığı sağlandı; ortalama ekstansör hareket açıklığı $10^{\circ}$ (dağılım, $0^{\circ}-30^{\circ}$ ) idi. Son takipte bir olguda osteoartrit görüldü, herhangi bir avasküler nekroz veya heterotrofik osifikasyon gözlenmedi. İki hastada vidaların çıkartılması gerekti. On hastada mükemmel ve beş hastada iyi sonuçlar elde edildi.

TARTIŞMA: Herbert vidasıyla fiksasyon kapitellar kırıklarda stabil bir tespit sağladığı gibi genişletilmiş lateral açınımla bu kompleks kırıkların internal fiksasyonu ardından dirsek hareketliliğinde iyi-mükemmel sonuçlar elde edilebilir.

Anahtar sözcükler: Açık redüksiyon ve internal fiksasyon; genişletilmiş lateral açınım; Herbert vidası; kapitellar kırık.

Ulus Travma Acil Cerrahi Derg 2017;23(6):507-5/4 doi: 10.5505/tjtes.2017.57|42 